\title{
Method to Assess the Level of Implementation of Productivity Practices on Construction Projects
}

\author{
Vikram S. Gohatre ${ }^{1}$, Amitkumar B. Ranit ${ }^{2}$ \\ ${ }^{1}$ PRMCEAM, Badnera - Amravati, Maharashtra, India \\ ${ }^{2}$ Professor, PRMCEAM, Badnera - Amravati
}

\begin{abstract}
It is unfortunate that the productivity in the construction industry has lagged behind the manufacturing industry for the last several decades. The research presented in this thesis aims to improve productivity in the infrastructure sector of the construction industry by developing Best Productivity Practices Implementation Index (BPPII) for Construction projects. The BPPII Infrastructure is a check list of practices that are considered to have a positive influence on labour productivity at the project level for infrastructure projects. These practices have been identified through a literature review and consultation with industry experts, and have been anecdotally proven to positively affect productivity. These practices have been grouped together into a formalized set of BPPII's categories, sections, and elements. Its planning and implementation levels have been defined. Each practice in the index has been assigned a relative weight based on its importance in affecting labor productivity. In total, there are 31 elements and 6 categories. The six categories of the BPPII Infrastructure are: (1) Materials Management; (2) Construction Machinery and Equipment Logistics; (3) Execution Approach; (4) Human Resources Management; (5) Construction Methods; and (6) Health and Safety. The PIL method is used to find maximum score of each category and each element. Further the category are ranked on the basis of the score obtained by the PIL. The categories Execution Approach score the highest in the entire category with the score of 146. Further the top 10 element are ranked according to their score.
\end{abstract}

Keywords: Labor productivity; Project planning; Management practices; Industrial projects; Implementation index

\section{Introduction}

This chapter introduces the basic definition of productivity and Best Productivity Practices Implementation Index which is develop by Construction Industry Institute's. Construction Labour productivity is one of the most prevalent problems affecting construction industry.

\subsection{General}

Over the last few decades, the construction industry has made significant progress through advances in heavy equipment, tools, and materials. Infrastructure projects are vital for the economic, social, and environmental well-being of a country. It is widely accepted that the quality of our infrastructure directly impacts the quality of life and economic prosperity of our communities. The construction industry is a major contributor to the economy of a nation, and infrastructure projects account for a major portion of the construction business.

The volume of infrastructure construction in the United States of America is much higher than India. These amounts are in addition to that required for the maintenance and rehabilitation of the existing infrastructure, the majority of which has reached its service or design life. All together, the volume of infrastructure construction will grow and with it the need to improve the construction productivity in order to optimize current and future construction expenditures. Construction productivity directly affects the prices of construction projects and the robustness of the national economy. It also affects the outcomes of the national efforts for the renewal of existing infrastructure systems, for building new infrastructure, and competitiveness in the global market
In a study undertaken by the Construction Industry Institute's (USA) Improving productivity is a management issue, and the use of new technologies and techniques may be helpful. Analysis by the Construction Industry Institute's (CII) Research Teams 240 and 252 of CII Benchmarking and Metrics data has clearly shown that productivity typically deviates $25 \%$ more or less from the norm on any particular project within a group with similar characteristics and environments.

Research team of CII developed a method, called the Best Productivity Practices Implementation Index for Industrial Projects (BPPII Industrial), that can be used by members of a construction project's management team to assist in the planning and implementation of management practices that have the potential to improve construction productivity on industrial projects. The goal of the BPPII Industrial is to produce a comprehensive checklist in the form of audits to assess the implementation levels of essential practices needed to ensure high levels of productivity by the craft workers. The method also provides a scoring system to quantitatively evaluate a project team's level of preparedness in addressing these issues. The practices included are those that are widely accepted throughout the construction industry

The research presented lays out a strategy to help improve the productivity of the infrastructure construction sector. It is based on the premise that what is measured will be improved. To effectively manage an industry, a project, or an activity, measurement tools are required. As a result, the proposed research was designed to improve the measurement of practices and the performance of productivity at the project level of the infrastructure construction sector by developing the Best Productivity 


\section{International Journal of Science and Research (IJSR) \\ ISSN (Online): 2319-7064}

Index Copernicus Value (2013): 6.14 | Impact Factor (2015): 6.391

Practices Implementation Index (BPPII) for infrastructure projects.

Industrial Projects is a tool designed to help project managers or superintendents plan productivity enhancing jobsite activities. The philosophy of the BPPII is that one can only improve what is measured. The BPPII-Industrial Projects measures the planning and implementation levels of practices that have the potential to improve construction productivity on industrial projects. These practices differ from the Construction Industry Institute (CII) Best Practices since the focus of BPPII is on practices that promote productivity improvement. The BPPII enables managers to identify practices with low implementation levels on their projects. And it helps them carry out practices that, as noted above, positively affect productivity. The BPPII should be used at the beginning of the execution phase, to help project managers identify the productivity-improving practices to be implemented at the construction site. However, it can also be used at the end of the detailed scope phase to help prepare the project execution plan.

Development of the Best Productivity Practices Implementation Index (BPPII) as a measurement tool as this research intends, has the potential to have a substantial impact in terms of its influence on improving the productivity of the industry during an especially crucial time in our history. Because of the total investments required in the infrastructure construction sector, improving construction labour productivity by only a few percent could save many tens or hundreds of millions of dollars in the years ahead.

In order for the construction industry to contribute to economic growth with other industries, construction productivity must grow along with other industries. Therefore, the productivity of a major sector like construction in a national economy is of great importance. Improving productivity in the infrastructure construction sector will help in improving productivity in the overall construction industry as it represents a major portion of the overall construction industry.

\subsection{Definition of Productivity in Construction Industry}

The productivity can be defined in many ways in construction industry. Productivity is a comparison between how much you have put into the projects in terms of manpower, material, machinery or tools and the result you get out of the project. Productivity has to do with the efficiency of production. Making a site more productive that means getting more output for less cost in less time. Productivity covers every activity that goes into completing the construction site works, from the planning stage to the final state. If the contractor can carry out these activities at lower cost in less time with fewer workers, or with less equipment then productivity will be improved. Productivity is generally defined as the ratio of outputs to inputs.

Productivity $=\frac{\text { Output }}{\text { Input }}$

It is important to specify the inputs and outputs to be measured when calculating productivity because there are many inputs, such as labour, materials, equipment, tools, capital, and design.

The conversion process from inputs to outputs associated with any operation is also complex, influenced by the technology used, by many externalities such as government regulations, weather, economic conditions, management, and various internal environmental components.

\subsection{What is Labour Productivity?}

Labour is one of the basic requirements in construction industry. Labour productivity is the most widely used standard to which other measurements or comparisons are judged of operational efficiency. This does not imply that labour is the best input element for productivity measurement but simply reflects the difficulty or impossibility of obtaining numerical values for the other determinants of productivity. One common measure of average labour productivity is a ratio of output per labour. In other words, definition of labour productivity is the amount of goods and services produce by a manpower in unit of time.

$$
\text { i.e. labour Productivity }=\frac{\text { Output }}{\text { Labour cost }}
$$

\subsection{Aim and Objectives}

The main aim of this research is to develop a process for improving project labour productivity in the infrastructure construction sector. This aim would be achieved by developing the Best Productivity Practices Implementation Index (BPPII) for infrastructure projects. The following objectives are required to achieve the main research objective

1) To identify and define the categories and element of the BPPII for Infrastructure projects

2) To find out the maximum score by PIL formula.

3) To rank the top ten elements in BPPII Infrastructure

These research objectives are achieved by identifying, mapping, and measuring processes or practices which are essential for improving construction productivity at the project level for the infrastructure construction sector and by collecting and analyzing data for validation.

\subsection{Scope}

The scope of the research was to identify potential best practices based on literature review and expert opinions like those of members of the Construction Industry Institute (CII) Research Team 252, and develop an implementation index based on these practices for increasing productivity at the project level for the infrastructure construction sector. Practices which have the potential of increasing construction productivity were identified and grouped together, and an implementation index was developed. The scope of the research was limited to the infrastructure construction sector and to differences in labour productivity at the project level.

\subsection{Organization of Project Report}

This project work is divided into five chapters. Chapter 2 deals with the review of literature. Chapter 3 presents

\section{Volume 5 Issue 6, June 2016} www.ijsr.net 


\section{International Journal of Science and Research (IJSR) \\ ISSN (Online): 2319-7064 \\ Index Copernicus Value (2013): 6.14 | Impact Factor (2015): 6.391}

detailed methodology to be adopted. Chapter 4 includes result and discussion. Chapter 5 presents the conclusion of the study

\section{Literature Review}

This chapter presents a review of relevant literature related to labour productivity and consists of definitions related to project and project management, details about factors affecting labour productivity, construction productivity. This chapter also states the hypotheses and propose conceptual model for this study.

(Carlos H. Caldas et al. 2014) analyzed various practices to improve the construction productivity. The main approach of author study was to improve the construction productivity. Thus best productivity practices implementation index method was used for industrial projects. Thus finding shows planning and implementation level practices are adopted. Various elements which influence construction labour productivity are taken into consideration. Author presents the development, verification, and validation for the bppii industrial. Another primary contributions of author are the identification of key productivity practices, quantification of the relative importance of these practices, development of a method to assess the level of implementation of these practices on project productivity performance and validation of the proposed method based on its implementation on several industrial projects. Through this review author concluded that many different factors are affecting project performance. The goal of the authors study was to improve the effective planning and implementing of management practices that positively impact construction productivity.

(Hassan Nasir 2013) several practices have been identified through a literature review and consultation with industry experts, and have been proven to positively affect productivity. BPPII Infrastructure is a check list of practices which are considered to have a positive influence on labour productivity. In BPPII the categories, sections, and elements are grouped together. Each practice and its planning and implementation levels had been completely defined. Each practice in the index had been assigned a relative weight based on its importance in affecting labour productivity. The six categories of the BPPII Infrastructure are: (1) Materials Management; (2) Construction Machinery and Equipment Logistics; (3) Execution Approach; (4) Human Resources Management; (5) Construction Methods; and (6) Health and Safety. Data were collected from questionnaire survey for infrastructure projects. Data analysis was done by PIL formula for all the categories. Through this review conclusion is drawn based on the statistical analysis of the productivity factor and BPPII scores. Projects that have a high score on the implementation of best practices as defined by the BPPII Infrastructure showed better productivity performance than those that have a low score on the implementation of best practices.

(Hassan Nasir et al. 2015) analyzed the productivity and project performance can be improved through implementing best practices. Author describes the development of best productivity practices implementation index (BPPII) for infrastructure project. In that the index is a checklist of practices are considered to have a positive influence on labour productivity at the project level for infrastructure project. Further these practices have been grouped together into a set of categories, section and elements. Each practice and its planning and implementation level were defined and assigned a relative weight on the basis of its importance in affecting labour productivity. Result shows the statistical tests which confirmed the higher implementation of best practices as defined in the index and have a strong positive relationship with the productivity factor and project schedule performance.

(Rojas and Aramvareekul 2003) conducted a survey on productivity drivers (e.g., materials management) and opportunities. The survey analysis of drivers regrouped the results under four categories: (1) management systems and strategies, (2) personnel, (3) industry environment, and (4) external conditions. They also noticed that certain factors have different impacts on labour productivity. The main finding of this research brings out the controllable characteristic of labour productivity, representing a huge opportunity for productivity improvements. Thus, labour productivity was seen as a manageable issue. Moreover, it is observed that the introduction of innovations helps to improve labour productivity but cannot solve all the problems related to it.

(Allmon et al. 2000) several studies was also attempted to assess construction labour productivity trends. These study had been tried to explain and understand the causes and implications of these trends. Further a study reviewed the principal factors affecting construction labour productivity. Six factors were identified by the author: (1) project uniqueness, (2) technology, (3) management, (4) labour organization, (5) real wage trends, and (6) construction training. After identifying the factors this study also categorized four ways to improve labour productivity through management practices (1) planning, (2) resource supply and control, (3) supply of information and feedback, and (4) selection of the right people to control certain factors.

(Shan et al. 2011) author has discuss relationship between the implementation level of management practices and mechanical labour productivity. They utilized the construction industry institute (CII) benchmarking and metrics data set from 41 projects. They found that four management practices have positive correlations with mechanical productivity improvement: (1) pre-project planning, (2) team building, (3) automation and integration of information systems, and (4) safety. Therefore, numerous research programs looked into the potential ways to improve management and make it more effective in supporting craft workers on a jobsite.

(Liberda et al. 2003) interviewed 20 industry experts with an average of 27 years of construction industry experience to examine the construction productivity impacts related to human, management, and external factors. Understanding the relationship between construction productivity and project performance is crucial for address the issues. The study investigated 51 factors 8 in the human category, 35 in that of management, and 8 in the external category. The 


\section{International Journal of Science and Research (IJSR) \\ ISSN (Online): 2319-7064 \\ Index Copernicus Value (2013): 6.14 | Impact Factor (2015): 6.391}

authors identified the top 15 factors that had the most significant impact on construction productivity as the following: (1) lack of detailed planning, (2) worker experience and skills, (3) inadequate supervision, (4) worker motivation, (5) non availability of materials, (6) worker attitude and morale, (7) crew team spirit, (8) non availability of information, (9) changes in drawings and specifications, (10) non availability of tools, (11) non availability of equipment, (12) project size and complexity, (13) lack of procedures for construction methods, (14) changes in contract, and (15) congested work areas. There are three management factors in the top five. This fact confirms the notion that productivity can be managed and was controllable through the effective implementation of certain management practices. This notion was crucial to improving construction productivity through implementing management practices.

(Dai et al. 2009) a more recent study was conducted on worker perceptions of these factors. The research surveyed 1,996 craft workers throughout the united states (including supervisors and general supervisors) to determine the overall priorities of 83 productivity factors according to craftsmen. At the same time, workers were asked to evaluate the overall labour productivity of their project. In addition, this survey was completed with a statistical analysis on the real impact on productivity of factors which were perceived as having low influence. The results of this survey show the following six categories, listed in order of importance, have the greatest impact on labour productivity: (1) tools and consumables, (2) materials, (3) engineering drawing management, (4) construction equipment availability, (5) supervisor direction, and (6) safety. Finally, this study raised a very important point about worker motivation. Workers appreciated the research program took account of their points of view. This suggests the huge influence that management practices have on labour productivity. However, this survey reveals that depending on the trade, the impacts of the categories varied. This should be taken into account in future studies when using craft worker input.

(Borcherding and Garner 1981) over the last few decades, the factors affecting labour productivity have received increasing attention among construction researchers. The U.S. Department of Energy conducted a survey of 12 construction projects. Among these industrial projects, the U.S. DOE surveyed both craft workers and supervisor to determine and quantify the diverse factors that both negatively and positively impact construction productivity and worker motivation. From the craftsmen questionnaire surveys, the researchers identified nine major factors and ranked them according to their relative impact on labour productivity: (1) material availability, (2) tool availability, (3) rework, (4) overcrowded work area, (5) inspection delays, (6) supervisor incompetence, (7) crew interfacing, (8) craft turnover and absenteeism, and (9) supervisor changes. Most of these factors are considered by many to be universal, and therefore can be generalized to the whole construction industry. However, others factors, such as the increased lead time in engineering design for these projects, are very specialized and unique and cannot be applied to all kinds of construction projects.
(Eddy M. Rojas 2003) labour productivity declined significantly in the construction industry during the 19791998 period. Author critically examines the construction labour productivity macroeconomic data to determine their validity and reliability. The method of Data collection, distribution, manipulation, analysis, and interpretation are reviewed and problems are identified. The main conclusion of the study was that the raw data used to calculate construction productivity values at the macroeconomic level. The uncertainty generated in the process of computing these values was such that it cannot be determined if labour productivity has actually increased, decreased, or remained constant in the construction industry.

(Paul M. Goodrum et al.) some new technologies promise to improve construction productivity, their ability to deliver was not always realized. A four-stage predictive model was developed and validated to estimate the potential for a technology to have a positive impact on construction productivity. The method adopted by author examine the four stages costs, feasibility, usage history, and technical impact of a technology. The predictive model combines results from historical analyses to formalize how selected technologies with improved construction productivity can be used as a predictor of how future technologies might do the same. Each of the stages of a predictive model was subdivided into a series of categories and questions, which were weighted by importance by using the analytical process. The predictive model was then validated by using 74 previous and existing construction technologies. From results statistical analysis confirmed that average performance scores produced by the model were significantly different across the categories of successful, inconclusive, and unsuccessful in the actual implementation experience of technologies.

(William F. Maloney 1983) labour has a significant influence on construction productivity. The level of productivity was a result of the driving, induced, and restraining forces acting upon workers. These forces act positively and negatively with regard to productivity improvement. Author presented a framework for analyzing the influence of each of these forces on four major labour related determinants of construction productivity. Approaches to productivity improvement are analyzed in terms of reducing the negative forces and strengthening the positive forces.

(Upul Ranasinghe1 et al. 2012) construction productivity improvement has become a key area to focus on industry. Despite its high impact on the construction industry, productivity improvement was still an area in which much research work needs to be done to find out true potential in industry. Author discusses a framework for the implementation of productivity improvement activities on a construction site, making the process more systematic and accountable with the creation of the construction productivity improvement.

(Jimmie Hinze and Gary Wilson 2000) in the past decade the terms "zero accidents" and "zero injuries" have been used a great deal by construction firms espousing their commitment to safety. Proposed work have shown many 


\section{International Journal of Science and Research (IJSR) \\ ISSN (Online): 2319-7064 \\ Index Copernicus Value (2013): 6.14 | Impact Factor (2015): 6.391}

construction firms, especially those in the industrial sector, have enjoyed significant improvements in their safety performances. A study was conducted to see if additional improvements could be made. The study was conducted with a selected group of large, primarily industrial, firms to determine if any changes had been made since the Construction Industry Institute publicized its findings on effective means to improve safety performance. Author conclude that safety performances have improved since these additional safety practices have been implemented. The implication was that firms with good safety records can still make improvements by implementing specific safety practices.

\section{Methodology}

This chapter explains the procedure of this study. A list of various elements which affect construction productivity were collected from the review of the literature and developed into a questionnaire. After preparing questionnaire, data was collected through the questionnaire survey and analyze the data by using PIL method and rank them according to their score.

\subsection{Process of Methodology}

The methodology process consists of six steps which are given in Figure 3.1.

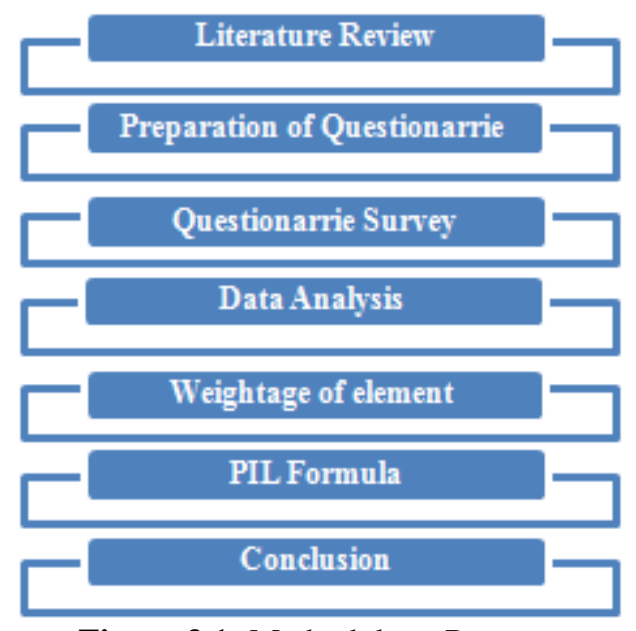

Figure 3.1: Methodology Process

\subsection{Questionnaire Design}

"Questionnaire Survey is defined as collection of different data by asking people questions". This questionnaire was designed for collecting information related to the Best Productivity Practices Implementation Index for Infrastructure projects. The tool was designed to be simple and easy to interpret. Data was collected from literature reviews which emphasize building construction's productivity. A survey was given to employees from different trades involved with the construction project.

The design strategy of the questionnaire was that the questions had to be simple, clear, and understandable for the respondents. The questionnaire has the definite advantages of requiring a smaller time to be responded and more accuracy in the final outcome. elements influencing construction labour productivity were identified through the literature survey. A total of 31 elements were identified. These 31 elements were classified under 6 group's i.e. Materials Management, Construction Machinery \& Equipment Logistics, Execution Approach, Human Resource Management, Construction Methods, Environment, Safety and Health which shown in table 3.1. The Materials Management group consists of 6 elements which influencing productivity. The construction machinery and equipment logistics group consists of 4 elements which influencing productivity. The Execution Approach group consists of 6 Execution related elements which influencing productivity. The Human Resource Management group consists of 5 elements such as age factors, working hours per day etc. The Construction Methods group consists of 4 elements which influence productivity. The Environment, Safety, and Health group consists of 6 elements such as safety of labours, work environment and health related terms.

The participants were required to rate the elements for the way they affect construction labour productivity, considering time, cost, and quality using their own experiences on building sites. The questionnaire required the respondents to rank the elements affecting labour productivity on a scale with the rating of 1 to 5 i. e. " 1 ," representing not important; " 2 ," representing low important; " 3 ," representing moderately important; “4," representing important; "5," representing very important, according to the degree of importance on construction labour productivity. The responses were to be based on the experiences, understanding and knowledge of the respondents and not related with any specific project. The method of questionnaire was simple and direct and this method was selected to establish a means of developing a list of elements impacting on labour productivity on construction projects.

\subsection{Categories and Elements of BPPII Infrastructure}

Table 3.1 provides a complete list of elements and categories that constitute the Best Productivity Practices Implementation Index (BPPII) for Infrastructure projects. The BPPII Infrastructure consists of six categories and 31 elements as shown in Table 3.1. These categories and Elements are described in detail below. 


\section{International Journal of Science and Research (IJSR) \\ ISSN (Online): 2319-7064}

Index Copernicus Value (2013): 6.14 | Impact Factor (2015): 6.391

Table 3.1: BPPII industrial categories and elements

\begin{tabular}{|c|c|c|}
\hline $\begin{array}{l}\text { Sr. } \\
\text { No }\end{array}$ & Categories & Elements \\
\hline \multirow{6}{*}{1} & \multirow{6}{*}{$\begin{array}{c}\text { Materials } \\
\text { Management }\end{array}$} & Defining accurate materials specifications \\
\hline & & $\begin{array}{l}\text { Locating sources of materials for } \\
\text { procurement }\end{array}$ \\
\hline & & Preparing for material storage \\
\hline & & $\begin{array}{c}\text { Daily recording of using materials in the } \\
\text { project }\end{array}$ \\
\hline & & Controlling over-ordering and purchasing \\
\hline & & $\begin{array}{l}\text { Co-workers are mishandling the materials } \\
\text { due to lack of training }\end{array}$ \\
\hline \multirow{4}{*}{2} & \multirow{4}{*}{$\begin{array}{c}\text { Construction } \\
\text { Machinery \& } \\
\text { Equipment } \\
\text { Logistics }\end{array}$} & $\begin{array}{l}\text { Procurement Procedures \& Plans for } \\
\text { Construction Machinery }\end{array}$ \\
\hline & & $\begin{array}{l}\text { Construction Machinery and Equipment } \\
\text { Maintenance }\end{array}$ \\
\hline & & $\begin{array}{l}\text { Site Tools and Equipment Management } \\
\text { Strategy }\end{array}$ \\
\hline & & On-site Tools Maintenance \\
\hline \multirow{6}{*}{3} & \multirow{6}{*}{$\begin{array}{l}\text { Execution } \\
\text { Approach }\end{array}$} & Short interval planning \\
\hline & & Well defined scope of work \\
\hline & & Use of Software \\
\hline & & Dedicated planner \\
\hline & & Model requirements/3d visualization \\
\hline & & Contracts \& Agreements with Agencies \\
\hline \multirow{5}{*}{4} & \multirow{5}{*}{$\begin{array}{c}\text { Human } \\
\text { Resource } \\
\text { Management }\end{array}$} & Age factor \\
\hline & & Average working hours/day \\
\hline & & $\begin{array}{l}\text { Site crowding factor enables labors to do } \\
\text { work in uncomfortable manner. }\end{array}$ \\
\hline & & $\begin{array}{l}\text { Over time work will not give good } \\
\text { productivity in an job }\end{array}$ \\
\hline & & $\begin{array}{l}\text { On time payment is done right at the time } \\
\text { when the work is accomplished. }\end{array}$ \\
\hline \multirow{4}{*}{5} & \multirow{4}{*}{$\begin{array}{c}\text { Construction } \\
\text { Methods }\end{array}$} & $\begin{array}{c}\text { The construction team (including the } \\
\text { owner, engineering and Procurement) was } \\
\text { both integrated and aligned. }\end{array}$ \\
\hline & & $\begin{array}{l}\text { Drawings, site permits, and other required } \\
\text { documents were Available before starting } \\
\text { construction. }\end{array}$ \\
\hline & & $\begin{array}{c}\text { All necessary material, equipment, tools } \\
\text { and work permits were available before } \\
\text { starting construction. }\end{array}$ \\
\hline & & $\begin{array}{l}\text { Required construction and management } \\
\text { personnel were available as needed before } \\
\text { starting construction. }\end{array}$ \\
\hline \multirow{6}{*}{6} & \multirow{6}{*}{$\begin{array}{c}\text { Environment, } \\
\text { Safety, and } \\
\text { Health }\end{array}$} & Formal Health and Safety Policy \\
\hline & & $\begin{array}{c}\text { Climatic condition will affect your working } \\
\text { performance }\end{array}$ \\
\hline & & $\begin{array}{l}\text { Site safety procedures were followed for the } \\
\text { project. }\end{array}$ \\
\hline & & Safety incentives were used on the project. \\
\hline & & Accidents were formally investigated. \\
\hline & & $\begin{array}{l}\text { Contractor employees were randomly } \\
\text { screened for alcohol and Drugs. }\end{array}$ \\
\hline
\end{tabular}

\subsubsection{Category I - Materials Management}

The first category in the index is materials management, and practices related to materials management are grouped in this category. Materials management is concerned with the availability of the right materials at the right time and at the right place in the construction process. Materials management has been identified as one of the most important factors affecting construction projects in several research efforts. Materials management has been identified as a best practice by CII. Effective materials management on a construction project has the ability to improve productivity and reduce crew idle time. Research found that inefficient materials management could be responsible for an increase in field labour hours of $50 \%$ or more.

\subsubsection{Category II - Construction Machinery and Equipment Logistics}

The CII conducted the Voice of the Worker Index research project and determined that the factors having the most significant impact on craft labour productivity was the availability of appropriate construction equipment and tools on jobsites. Research reported that the most significant factor affecting craft labour productivity in workers' view is that, "I have to wait for people and/or equipment to move the material I need". Research supported the importance of using a site tool management plan to ensure tools are present on site, stored in a location that is organized and easy to locate, and in proper condition to perform designated tasks. Research found that tools, equipment, and trucks are some of the main factors that can decrease productivity if they are not managed properly. They also reported that tools and equipment and trucks account for a major portion of the total waiting time. Research reported that construction machinery have high significance in factors related to working conditions.

\subsubsection{Category III - Execution Approach}

This category deals with issues which are required to be planned and settled so that the construction work can be properly executed and progresses without stopping. The practices in this category are related to planning, constructability reviews, utility alignments, acquisition strategies, and regulatory requirements. They reported that fixed price contracts have better productivity and that lowest bid contracts had a negative effect on productivity. They also mentioned that planning, scheduling, and availability of working drawings are critical for project productivity.

\subsubsection{Category IV - Human Resources Management}

As labour productivity involves humans, it is imperative that proper management of this resource is essential. Human Resources Management deals with the planning, training and development, organizational structure, and employment issues of people working in the company. Research identified lack of experienced design and project management personnel, restrictive union rules, and lack of management training for supervision and project management as the main factors affecting productivity.

\subsubsection{Category V - Construction Methods}

Construction methods used for the completion of a project play an important role in project success. This category groups together best practices related to site layout planning, scheduling controls, and design/construction planning and approach. Ineffective communications and inadequate planning and scheduling as major impediments in productivity improvement. Scheduling, overtime strategies, and task sequencing have greater impact on labour productivity

\subsubsection{Category VI - Health and Safety}

Health and Safety category relates to the implementation of practices that ensure the safety and health of workers and 


\section{International Journal of Science and Research (IJSR) \\ ISSN (Online): 2319-7064 \\ Index Copernicus Value (2013): 6.14 | Impact Factor (2015): 6.391}

managers on construction sites. The CII Benchmarking and Metrics program have metrics related to health and safety measurement (CII 2006a) and the Construction Sector Council Canada's Labour Productivity and Project Performance Improvement Program has also metrics defined for health and safety related practices. CII developed practices such as Zero Accident Techniques that should be implemented to protect workers' safety on a jobsite. The construction industry is one of the hazardous industries. The numbers of fatalities and injuries in the construction industry. His research found that accidents can be avoided by establishing procedures and regulations to enhance safety. Different job classifications have safety hazards related to them and usually the construction workers underestimate the hazards. The cost of accidents in construction accounts to approximately $6 \%$ of total building costs

\subsection{Data Collection}

The questionnaire was designed for collecting information related to the Best Productivity Practices Implementation Index for Construction projects. Questionnaire survey was carried out at different construction sites, such as government organization and private firm. 31 factors are classified under 6 categories are distributed to respondents. Total 31 respondents give their opinion out of 50 respondents.

\subsection{Weightage of Element}

The five-point scale ranged from 1 (not important) to 5 (extremely important) were adopted and transformed to relative importance indices. The value of $\Sigma \mathrm{W}$ is calculated by the sum of total 5 responses multiply by weightage given by the respondent. After that average has been calculated for getting PIL 5 score, where:

$\Sigma \mathrm{w}=$ sum of the weights assigned by the respondents

\subsection{Linear Interpolation by PIL}

After assigning the maximum scores to each category, the next step is to assign the relative scores to each PIL of all the 31 elements in the BPPII Infrastructure. The elements that are not applicable to a construction project are given a score of 0 . A level one of planning and implementation was given a score of 1 for all the elements. The scores of the PIL 2 to PIL 4 were determined based on linear interpolation between PIL 1 and PIL 5 using the following formulas:

PIL 2 Score $=($ PIL 5 Score -1$) / 4+1$

PIL 3 Score $=($ PIL 5 Score -1$) / 4+$ PIL 2 Score

PIL 4 Score $=($ PIL 5 Score -1$) / 4+$ PIL 3 Score

\subsection{Scoring of the BPPII Infrastructure}

Each element of the BPPII is scored using a system that ranks the planning and implementation level (PIL). The PIL definitions are organized on a scale from 0 to 5 . The guideline for each PIL is explained as below:

1) Planning and Implementation Level 0: The planning and implementation of the element is not applicable.

2) Planning and Implementation Level 1: The planning and implementation of the element is not addressed in any capacity on the project.

3) Planning and Implementation Level 2: The planning and implementation of the element is addressed up to a certain extent, but in a below average manner.

4) Planning and Implementation Level 3: The element has average level of planning and implementation.

5) Planning and Implementation Level 4: The planning and implementation of the element is thorough, above average, but not perfect.

6) Planning and Implementation Level 5: The element has the highest possible planning and implementation level, i.e. at most state of the art and technologically advanced level. It is expected that few projects would achieve this level.

\section{Results and Discussion}

This chapter presents results of responses received from the respondents. It also shows the relative importance index and planning implementation level of various studied factors for the above mentioned group of respondents.

This study involves a questionnaire survey approach from which statistical data was collected to answer questions in respect of the main subject of study. Questionnaire is the main tool used. Figure 4.1 represents the percentage of responses received from representatives of civil engineer, contractor, consultant.. The questionnaire survey was carried out by meeting various respondents which resulted in total sample size of 50 . Out of 50 questionnaires distributed, 31 were completed, returned and considered i.e. Response rate of $62 \%$ were from civil engineer, contractor, consultant.

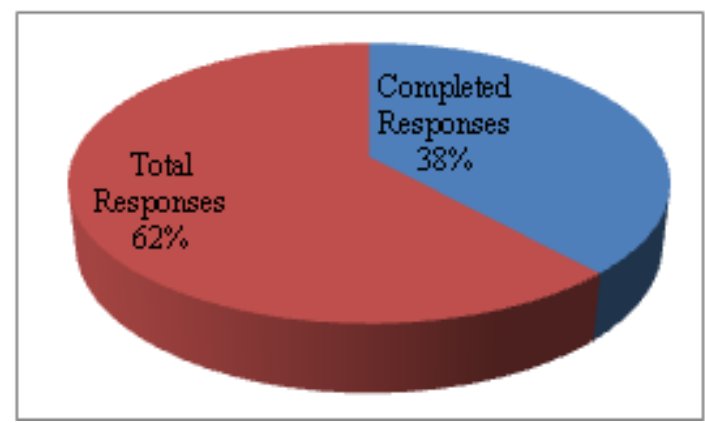

Figure 4.1: Percentages of Respondents

Weightage are assign to all the category like material management, Construction Machinery \& Equipment Logistics, Execution Approach, Human Resource Management, Construction Methods and Environment, Safety, and Health. Further the average value is calculated after analysis and assign to the respective element. 
International Journal of Science and Research (IJSR)

ISSN (Online): 2319-7064

Index Copernicus Value (2013): 6.14 | Impact Factor (2015): 6.391

Table 4.1: Weightage of Element

\begin{tabular}{|c|c|c|c|c|c|c|c|c|}
\hline \multirow{2}{*}{ Group } & \multirow{2}{*}{ Element } & \multicolumn{5}{|c|}{ Response } & \multirow{2}{*}{$\begin{array}{l}\text { Total } \\
(N)\end{array}$} & \multirow{2}{*}{$\Sigma W$} \\
\hline & & 1 & 2 & 3 & 4 & 5 & & \\
\hline \multirow{6}{*}{$\begin{array}{c}\text { Materials } \\
\text { Management }\end{array}$} & Defining accurate materials specifications & 1 & 2 & 5 & 3 & 20 & 31 & 132 \\
\hline & Locating sources of materials for procurement & 0 & 2 & 9 & 18 & 2 & 31 & 113 \\
\hline & Preparing for material storage & 0 & 8 & 14 & 6 & 3 & 31 & 97 \\
\hline & Daily recording of using materials in the project & 2 & 5 & 12 & 8 & 4 & 31 & 100 \\
\hline & Controlling over ordering and purchasing & 1 & 2 & 11 & 13 & 4 & 31 & 110 \\
\hline & Co-workers are mishandling the materials due to lack of training & 1 & 12 & 9 & 5 & 4 & 31 & 92 \\
\hline \multirow{4}{*}{$\begin{array}{c}\text { Construction } \\
\text { Machinery \& } \\
\text { Equipment } \\
\text { Logistics }\end{array}$} & Procurement Procedures \& Plans for Construction Machinery & 0 & 3 & 13 & 10 & 5 & 31 & 110 \\
\hline & Construction Machinery and Equipment Maintenance & 0 & 4 & 2 & 15 & 10 & 31 & 124 \\
\hline & Site Tools and Equipment Management Strategy & 0 & 2 & 14 & 8 & 7 & 31 & 113 \\
\hline & On site Tools Maintenance & 0 & 3 & 8 & 16 & 4 & 31 & 114 \\
\hline \multirow{6}{*}{$\begin{array}{l}\text { Execution } \\
\text { Approach }\end{array}$} & Short interval planning & 1 & 6 & 12 & 10 & 2 & 31 & 99 \\
\hline & Well defined scope of work & 0 & 0 & 9 & 17 & 5 & 31 & 120 \\
\hline & Use of Software & 0 & 3 & 2 & 12 & 14 & 31 & 130 \\
\hline & Dedicated planner & 0 & 2 & 4 & 15 & 10 & 31 & 126 \\
\hline & Model requirements/3d visualization & 2 & 2 & 0 & 20 & 7 & 31 & 121 \\
\hline & Contracts \& Agreements with Agencies & 0 & 0 & 3 & 13 & 15 & 31 & 136 \\
\hline \multirow{5}{*}{$\begin{array}{c}\text { Human } \\
\text { Resource } \\
\text { Management }\end{array}$} & Age factor & 3 & 5 & 12 & 8 & 3 & 31 & 96 \\
\hline & Average working hours/day & 1 & 3 & 13 & 12 & 2 & 31 & 104 \\
\hline & Site crowding factor enables labours to do work in uncomfortable manner. & 0 & 7 & 10 & 14 & 0 & 31 & 100 \\
\hline & Over time work will not give good productivity in an job & 0 & 15 & 11 & 4 & 1 & 31 & 84 \\
\hline & On time payment is done right at the time when the work is accomplished. & 3 & 13 & 11 & 4 & 0 & 31 & 78 \\
\hline \multirow{4}{*}{$\begin{array}{l}\text { Construction } \\
\text { Methods }\end{array}$} & $\begin{array}{l}\text { The construction team (including the owner, engineering and Procurement) was both } \\
\text { integrated and aligned. }\end{array}$ & 0 & 4 & 11 & 15 & 1 & 31 & 102 \\
\hline & $\begin{array}{l}\text { Drawings, site permits, and other required documents were available before starting } \\
\text { construction. }\end{array}$ & 0 & 3 & 3 & 17 & 8 & 31 & 123 \\
\hline & $\begin{array}{l}\text { All necessary material, equipment, tools and work permits were available before starting } \\
\text { construction. }\end{array}$ & 0 & 2 & 2 & 23 & 4 & 31 & 122 \\
\hline & $\begin{array}{c}\text { Required construction and management personnel were available as needed before starting } \\
\text { construction. }\end{array}$ & 0 & 4 & 3 & 19 & 5 & 31 & 118 \\
\hline \multirow{6}{*}{$\begin{array}{c}\text { Environment } \\
\text { Safety, and } \\
\text { Health }\end{array}$} & Formal Health and Safety Policy & 4 & 2 & 18 & 5 & 2 & 31 & 87 \\
\hline & Climatic condition will affect your working performance & 4 & 6 & 12 & 6 & 3 & 31 & 91 \\
\hline & Site safety procedures were followed for the project. & 0 & 14 & 11 & 4 & 2 & 31 & 87 \\
\hline & Safety incentives were used on the project. & 2 & 15 & 9 & 4 & 1 & 31 & 80 \\
\hline & Accidents were formally investigated. & 0 & 16 & 9 & 4 & 2 & 31 & 85 \\
\hline & Contractor employees were randomly screened for alcohol and drugs. & 2 & 13 & 8 & 6 & 2 & 31 & 86 \\
\hline
\end{tabular}

\subsection{PIL Score For Material Management}

Table 4.3 All of the elements that are N/A to a construction project, for whatever reason, are given a score of zero. A Level 1 of planning and implementation was given a score of 1 for all the elements. The maximum average value is calculated from $\Sigma \mathrm{W}$ for getting the value of PIL 5 i.e. In this case 26 is the maximum value for Defining accurate materials specifications. After that PIL 2, PIL 3, PIL 4 are calculated from the given formula. The maximum score is obtained for the category of material management is as 129 .

Table 4.2: PIL Score for Material Management

\begin{tabular}{|c|c|c|c|c|c|c|}
\hline Element & PIL0 & PIL1 & PIL2 & PIL3 & PIL4 & PIL5 \\
\hline Defining accurate materials specifications & 0 & 1 & 7 & 14 & 20 & 26 \\
\hline Locating sources of materials for procurement & 0 & 1 & 6 & 12 & 17 & 23 \\
\hline Preparing for material storage & 0 & 1 & 6 & 10 & 15 & 19 \\
\hline Daily recording of using materials in the project & 0 & 1 & 6 & 11 & 15 & 20 \\
\hline Controlling over ordering and purchasing & 0 & 1 & 6 & 12 & 17 & 22 \\
\hline $\begin{array}{c}\text { Co-workers are mishandling the materials due to lack } \\
\text { of training }\end{array}$ & 0 & 1 & 5 & 10 & 14 & 18 \\
\hline Maximum score of material management \\
\hline
\end{tabular}

Fig 4.2 shows that The element Defining accurate materials specifications has the highest score of 26. Locating sources of materials for procurement the score is 23. Preparing for material storage the score is 19 . Daily recording of using materials in the project has a score of 20. Controlling over ordering and purchasing has a score of 22. Where Coworkers are mishandling the materials due to lack of training has the lowest score in the category that is 18 . 


\section{International Journal of Science and Research (IJSR) \\ ISSN (Online): 2319-7064}

Index Copernicus Value (2013): 6.14 | Impact Factor (2015): 6.391

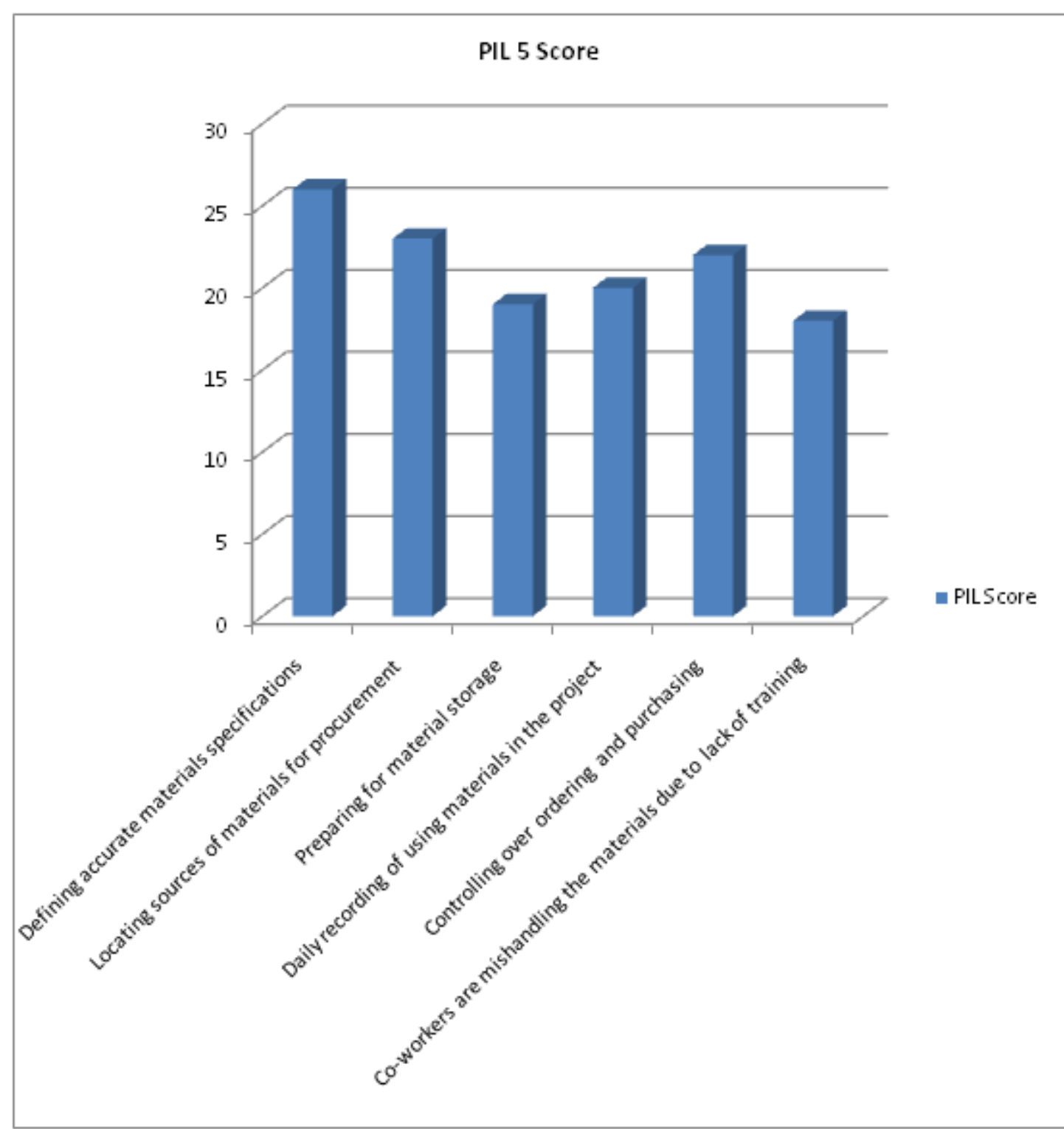

Figure 4.2: Maximum PIL score of material management

\subsection{PIL Score For Construction Machinery \& Equipment Logistics}

Table 4.4 All of the elements that are N/A to a construction project, for whatever reason, are given a score of zero. A Level 1 of planning and implementation was given a score of 1 for all the elements. The maximum average value is calculated from $\Sigma \mathrm{W}$ for getting the value of PIL 5 i.e. In this case 22 is the maximum value for Procurement Procedures \& Plans for Construction Machinery. After that PIL 2, PIL 3, PIL 4 are calculated from the given formula. The maximum score is obtained for the category of Construction Machinery \& Equipment Logistics is as 92.2.

Table 4.3: PIL Score For Construction Machinery \& Equipment Logistics

\begin{tabular}{|c|c|c|c|c|c|c|c|}
\hline Element & PIL0 & PIL1 & ILL2 & PIL3 & PIL4 & PIL5 \\
\hline Procurement Procedures \& Plans for Construction Machinery & 0 & 1 & 6.25 & 11.5 & 16.75 & 22 \\
\hline Construction Machinery and Equipment Maintenance & 0 & 1 & 6.95 & 12.9 & 18.85 & 24.8 \\
\hline Site Tools and Equipment Management Strategy & 0 & 1 & 6.4 & 11.8 & 17.2 & 22.6 \\
\hline On site Tools Maintenance & 0 & 1 & 6.45 & 11.9 & 17.35 & 22.8 \\
\hline Maximum score of Construction Machinery \& Equipment Logistics & & $\mathbf{9 2 . 2}$ \\
\hline
\end{tabular}

Fig 4.3 shows that The element Construction Machinery and Equipment Maintenance score 24.8, highest in this category. On site Tools Maintenance has a score of 22.8. Site Tools and Equipment Management Strategy has a score of 22.6, where Procurement Procedures \& Plans for Construction Machinery obtained a score of 22 which is lowest in the category.

\section{Volume 5 Issue 6, June 2016 www.ijsr.net}




\section{International Journal of Science and Research (IJSR) \\ ISSN (Online): 2319-7064}

Index Copernicus Value (2013): 6.14 | Impact Factor (2015): 6.391

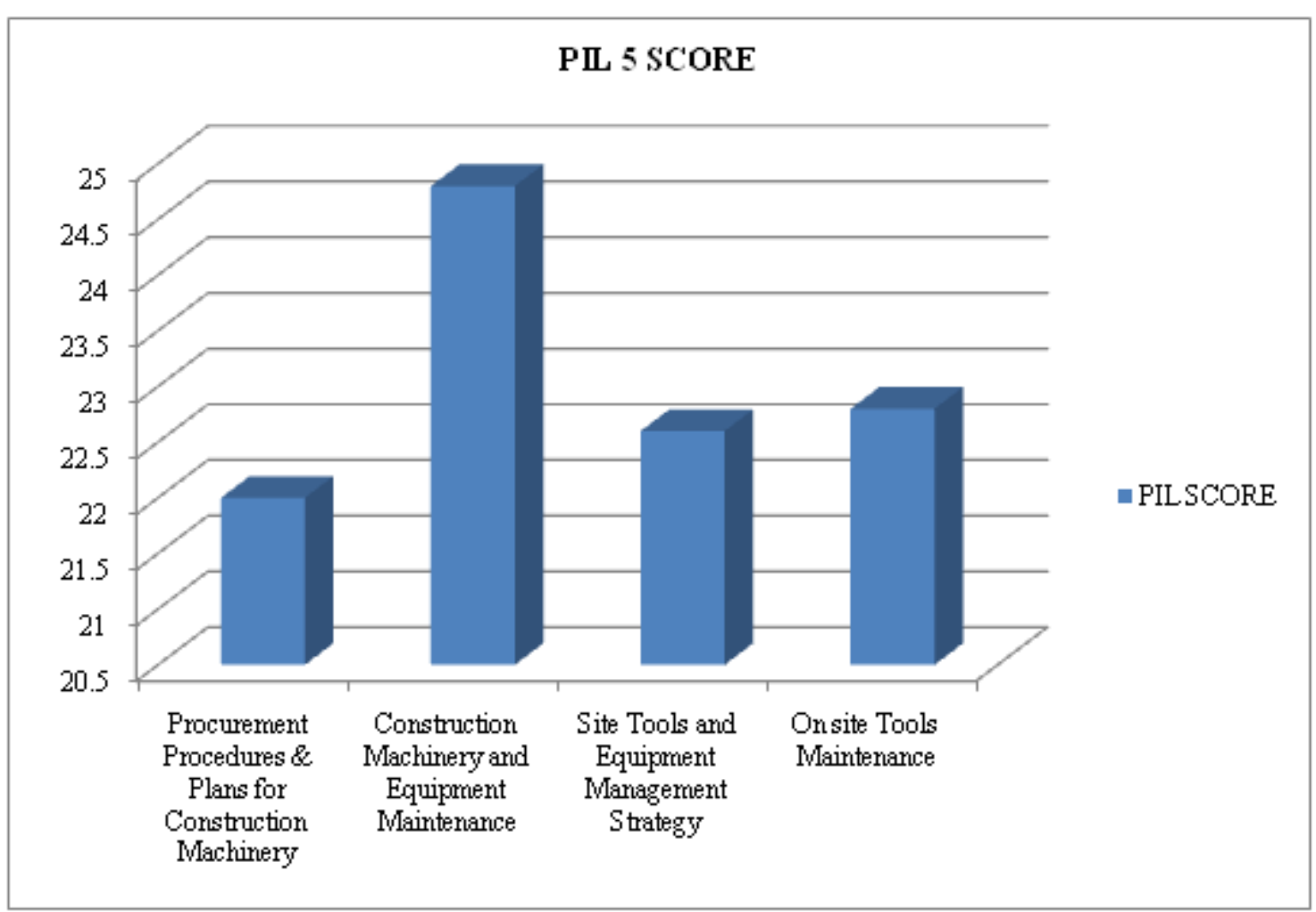

Figure 4.3: Maximum PIL score of Construction Machinery \& Equipment Logistics

\subsection{PIL Score for Execution Approach}

Table 4.5 shows that all of the elements that are N/A to a construction project, for whatever reason, are given a score of zero. A Level 1 of planning and implementation was given a score of 1 for all the elements. The maximum average value is calculated from $\Sigma \mathrm{W}$ for getting the value of PIL 5 i.e. In this case 20 is the maximum value for Short interval planning. Maximum score for the category of Execution Approach is obtained as 146. This is the highest score in the entire category.
Table 4.4: PIL Score For Execution Approach

\begin{tabular}{|c|c|c|c|c|c|c|}
\hline Element & PIL0 & PIL1 & PIL2 & PIL3 & PIL4 & PIL5 \\
\hline Short interval planning & 0 & 1 & 6 & 10 & 15 & 20 \\
\hline $\begin{array}{c}\text { Well defined scope of } \\
\text { work }\end{array}$ & 0 & 1 & 7 & 13 & 18 & 24 \\
\hline Use of Software & 0 & 1 & 7 & 14 & 20 & 26 \\
\hline Dedicated planner & 0 & 1 & 7 & 13 & 19 & 25 \\
\hline $\begin{array}{c}\text { Model requirements/3d } \\
\text { visualization }\end{array}$ & 0 & 1 & 7 & 13 & 18 & 24 \\
\hline $\begin{array}{c}\text { Contracts \& } \\
\text { Agreements with } \\
\text { Agencies }\end{array}$ & 0 & 1 & 8 & 14 & 21 & 27 \\
\hline \multicolumn{7}{|c|}{ Maximum score of Execution Approach } \\
\hline
\end{tabular}

Fig 4.4 shows that Contracts \& Agreements with Agencies has obtained highest score in all the elements that is 27 . Use of Software has a score of 26. Dedicated planner has a score of 25. Well defined scope of work and Model requirements/3d visualization scored 24 . Where the short interval planning obtained lowest score in this category that is 20 . 


\section{International Journal of Science and Research (IJSR) \\ ISSN (Online): 2319-7064}

Index Copernicus Value (2013): 6.14 | Impact Factor (2015): 6.391

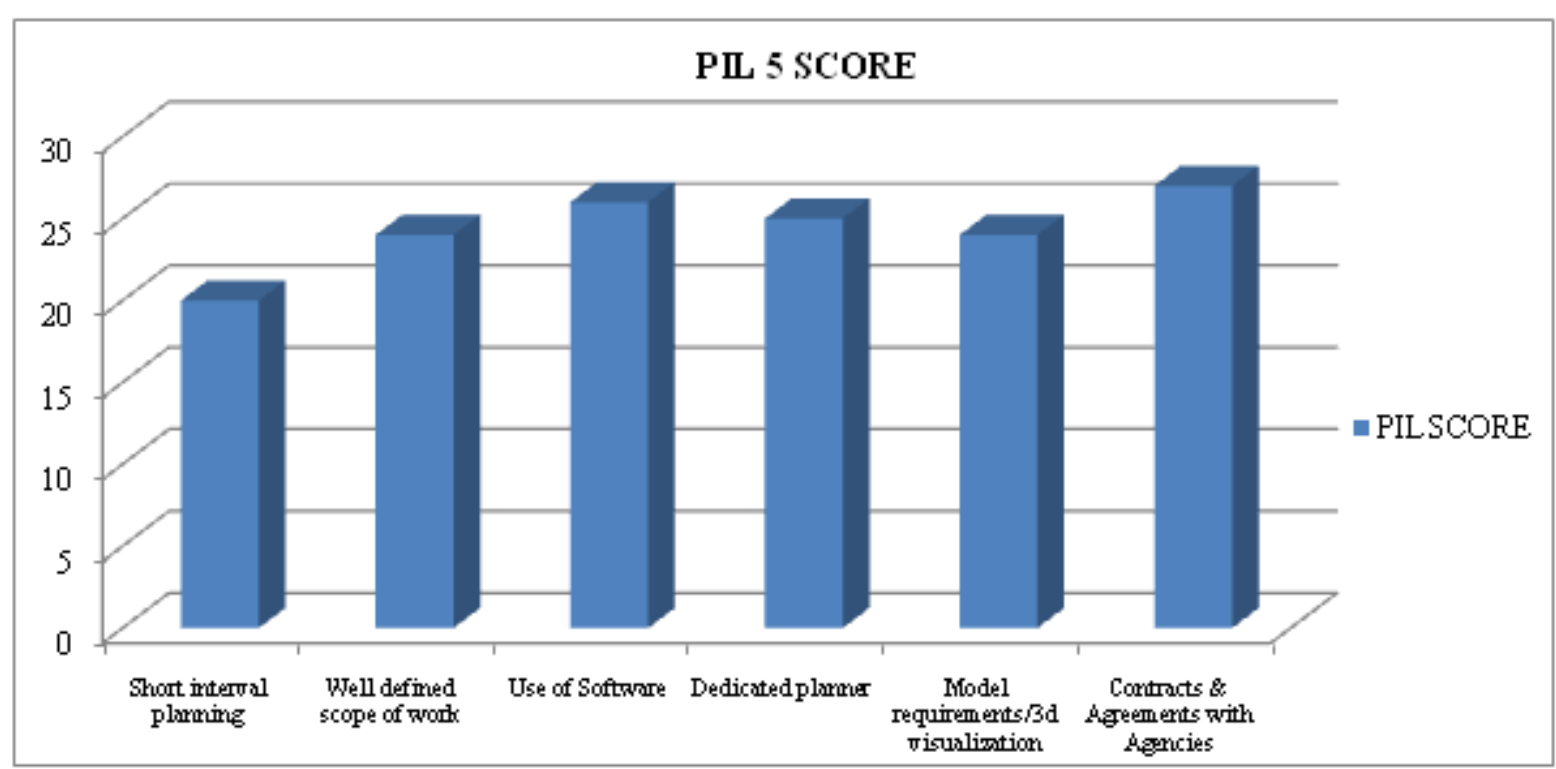

Figure 4.4: Maximum PIL score of Execution Approach

\subsection{PIL Score for Human Resource Management}

Table 4.6 shows that all of the elements that are N/A to a construction project, for whatever reason, are given a score of zero. A Level 1 of planning and implementation was given a score of 1 for all the elements. The maximum average value is calculated from $\Sigma \mathrm{W}$ for getting the value of PIL 5 i.e. In this case 19.2 is the maximum value for Age factor. Maximum score for the category of Human Resource Management Category is obtained as 92.4.
Table 4.5: PIL Score for Human Resource Management

\begin{tabular}{|c|c|c|c|c|c|c|}
\hline Element & PIL0 & PIL1 & PIL2 & PIL3 & PIL4 & PIL5 \\
\hline Age factor & 0 & 1 & 5.55 & 10.1 & 14.65 & 19.2 \\
\hline Average working hours/day & 0 & 1 & 5.95 & 10.9 & 15.85 & 20.8 \\
\hline $\begin{array}{c}\text { Site crowding factor enables } \\
\text { labors to do work in } \\
\text { uncomfortable manner. }\end{array}$ & 0 & 1 & 5.75 & 10.5 & 15.25 & 20 \\
\hline $\begin{array}{c}\text { Over time work will not give } \\
\text { good productivity in an job }\end{array}$ & 0 & 1 & 4.95 & 8.9 & 12.85 & 16.8 \\
\hline $\begin{array}{c}\text { On time payment is done } \\
\text { right at the time when the } \\
\text { work is accomplished. }\end{array}$ & 0 & 1 & 4.65 & 8.3 & 11.95 & 15.6 \\
\hline Maximum score of Human Resource Management & 92.4 \\
\hline
\end{tabular}

Fig 4.5 shows that the element, Average working hours/day has highest score 20.8. Site crowding factor enables labours to do work in uncomfortable manner has score 20. Age factor has score 19.2. Over time work will not give good productivity in an job has score 16.8 and the least score is obtained by On time payment is done right at the time when the work is accomplished that is 15.6 .

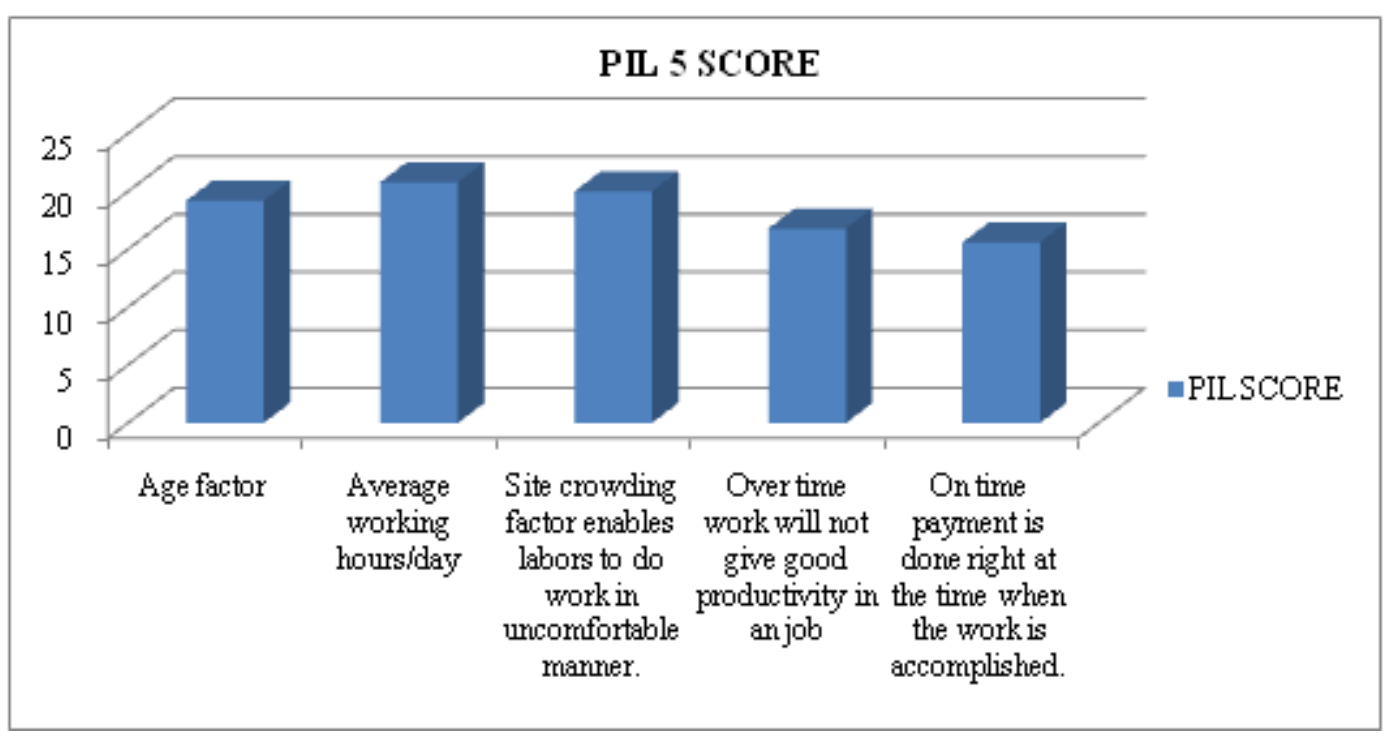

Figure 4.5: Maximum PIL score of Human Resource Management

\section{Volume 5 Issue 6, June 2016 www.ijsr.net}




\section{International Journal of Science and Research (IJSR) \\ ISSN (Online): 2319-7064 \\ Index Copernicus Value (2013): 6.14 | Impact Factor (2015): 6.391}

\subsection{PIL Score for Construction Methods}

Table 4.7 shows that all of the elements that are N/A to a construction project, for whatever reason, are given a score of zero. A Level 1 of planning and implementation was given a score of 1 for all the elements. The maximum average value is calculated from $\Sigma \mathrm{W}$ for getting the value of
PIL 5 i.e. In this case 20 is the maximum value for the construction team (including the owner, engineering and Procurement) was both integrated and aligned. The maximum score for the category of Construction Methods has obtained the score of 93 .

Table 4.6: PIL Score for Construction Methods

\begin{tabular}{|c|c|c|c|c|c|c|}
\hline $\begin{array}{c}\text { Element } \\
\text { The construction team (including the owner, engineering and Procurement) was both integrated } \\
\text { and aligned. }\end{array}$ & 0 & 1 & 6 & 11 & 16 & 20 \\
\hline $\begin{array}{c}\text { Drawings, site permits, and other required documents were available before starting } \\
\text { construction. }\end{array}$ & 0 & 1 & 7 & 13 & 19 & 25 \\
\hline $\begin{array}{c}\text { All necessary material, equipment, tools and work permits were available before starting } \\
\text { construction. }\end{array}$ & 0 & 1 & 7 & 13 & 19 & 24 \\
\hline $\begin{array}{c}\text { Required construction and management personnel were available as needed before starting } \\
\text { construction. }\end{array}$ & 0 & 1 & 7 & 12 & 18 & 24 \\
\hline Maximum score of Construction Methods & PIL5 \\
\hline \multicolumn{2}{c|}{} & & 93 \\
\hline
\end{tabular}

Fig 4.6 shows that the element Drawings, site permits, and other required documents were available before starting construction has the highest score that is 25 . All necessary material, equipment, tools and work permits were available before starting construction and Required construction and management personnel were available as needed before starting construction has score 24 . And the element that has score the least is The construction team (including the owner, engineering and Procurement) was both integrated and aligned is 20 .

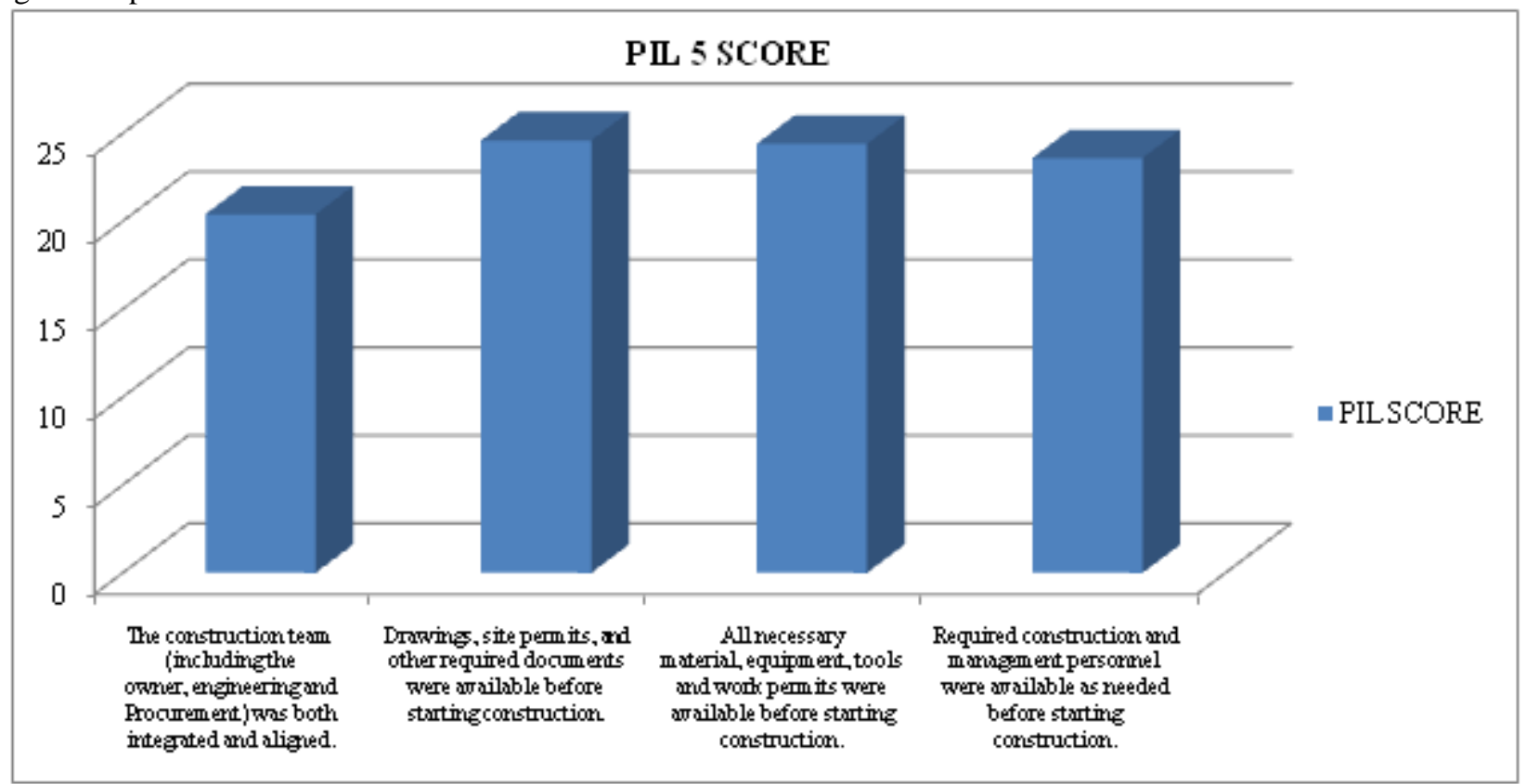

Figure 4.6: Maximum PIL score of Construction Methods

\subsection{PIL Score for Environment, Safety and Health}

Table 4.8 shows that all of the elements that are N/A to a construction project, for whatever reason, are given a score of zero. A Level 1 of planning and implementation was given a score of 1 for all the elements. The maximum average value is calculated from $\Sigma \mathrm{W}$ for getting the value of PIL 5 i.e. In this case 17 is the maximum value for The Formal Health and Safety Policy. The Maximum score for the category of Environment, Safety, and Health is obtained as 102 .

Table 4.7: PIL Score For Environment, Safety, And Health

\begin{tabular}{|c|c|c|c|c|c|c|}
\hline Element & PIL0 & PIL1 & PIL2 & PIL3 & PIL4 & PIL5 \\
\hline Formal Health and Safety Policy & 0 & 1 & 5 & 9 & 13 & 17 \\
\hline Climatic condition will affect your working performance & 0 & 1 & 5 & 10 & 14 & 18 \\
\hline Site safety procedures were followed for the project. & 0 & 1 & 6 & 9 & 13 & 17 \\
\hline Safety incentives were used on the project. & 0 & 1 & 4 & 8 & 12 & 16 \\
\hline Accidents were formally investigated. & 0 & 1 & 5 & 9 & 13 & 17 \\
\hline Contractor employees were randomly screened for alcohol and drugs. & 0 & 1 & 5 & 9 & 13 & 17 \\
\hline \multicolumn{6}{|c|}{ Maximum score of Environment, Safety, and Health } & 102 \\
\hline
\end{tabular}

Volume 5 Issue 6, June 2016 www.ijsr.net

Licensed Under Creative Commons Attribution CC BY 


\section{International Journal of Science and Research (IJSR) \\ ISSN (Online): 2319-7064 \\ Index Copernicus Value (2013): 6.14 | Impact Factor (2015): 6.391}

Fig 4.7 shows that the element 'Climatic condition will affect your working performance' has the highest score of 18. Formal Health and Safety Policy, Site safety procedures were followed for the project, Accidents were formally investigated and Contractor employees were randomly screened for alcohol and drugs has score of 17. And the element that has score the least is Safety incentives were used on the project that is 16 .

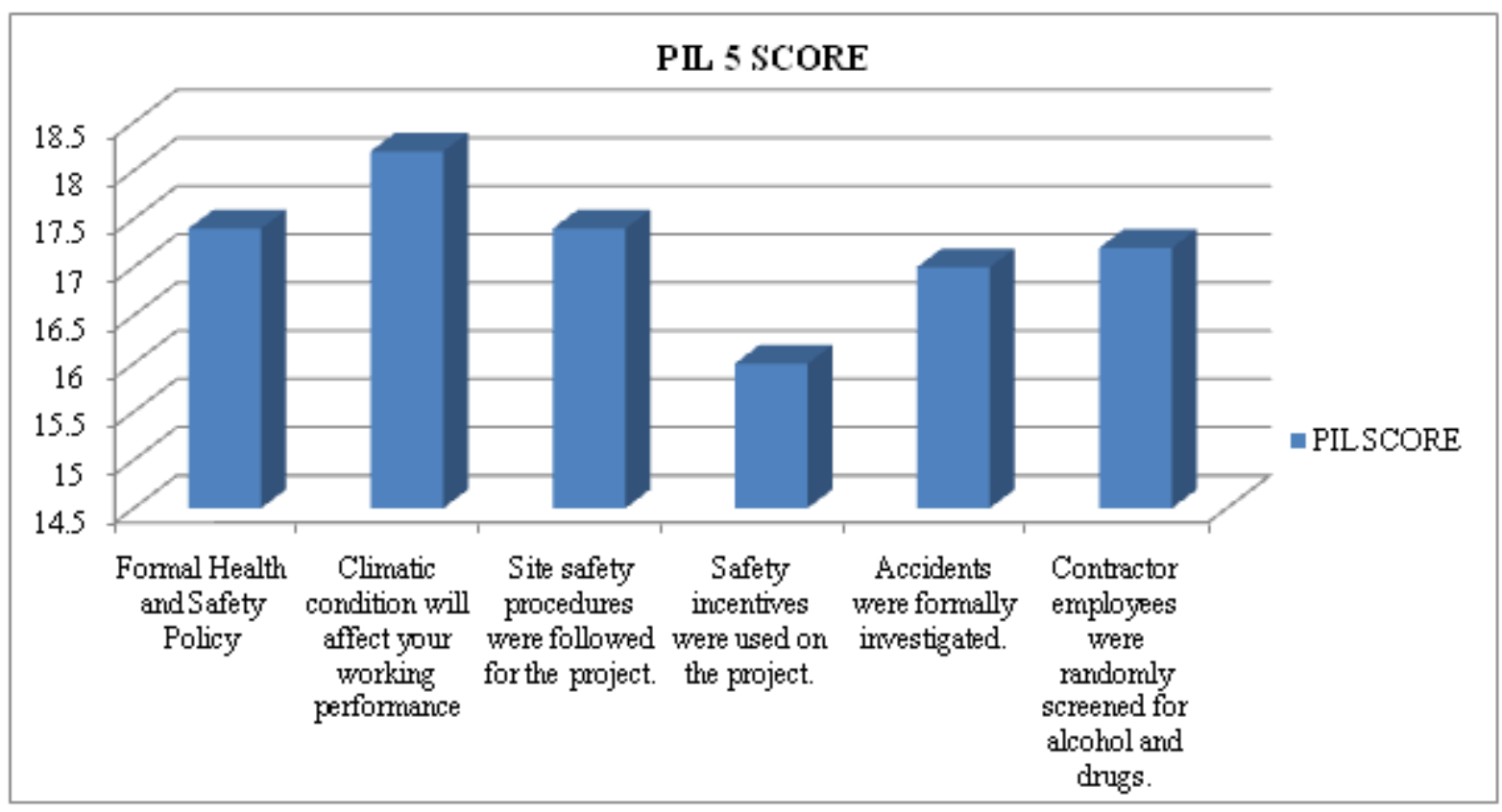

Figure 4.7: Maximum PIL score of Environment, Safety, and Health

Using survey data from 31 completed forms, the average importance factor of each category, and element was calculated. Once the averages had been calculated, the maximum scores of the 31 elements and 6 categories were determined. This corresponded to a situation in which the planning and implementation level (PIL) of all elements was 5 (i.e., maximum) on a 1 to 5 scale. The research team defined that the maximum attainable BPPII Industrial score for a project was set to 656, representing the best level of practice planning and implementation (i.e., all elements have a PIL of 5). The lowest score (i.e., all elements have a PIL of 1 with no nonapplicable elements) was set to zero.

Table 4.8: Maximum scores of the BPPII categories

\begin{tabular}{|c|c|}
\hline Category & Score \\
\hline CT.1 - Material Management & 129 \\
\hline CT.2 - Construction Machinery \& Equipment Logistics & 92.2 \\
\hline CT.3 - Execution Approach & 146 \\
\hline CT.4 - Human Resource Management & 92.4 \\
\hline CT.5 - Construction Methods & 93 \\
\hline CT.6 - Environment, Safety, and Health & 103 \\
\hline SUM & 656 \\
\hline
\end{tabular}

\section{7: Ranking of Categories in BPPII Infrastructure}

Table 4.9 shows the ranking of 6 categories in the BPPII infrastructure based on the score assigned to each of them.

Table 4.9: Ranking of Categories in BPPII Infrastructure

\begin{tabular}{|c|c|c|c|}
\hline $\begin{array}{c}\text { Ran } \\
k\end{array}$ & Category & $\begin{array}{c}\text { Relative } \\
\text { Score } \\
(\%)\end{array}$ & Score \\
\hline 1 & CT.3- Execution Approach & 22.31 & 146 \\
\hline 2 & CT.1- Material Management & 19.63 & 129 \\
\hline 3 & $\begin{array}{c}\text { CT.6- Environment, Safety, and } \\
\text { Health }\end{array}$ & 15.73 & 102 \\
\hline 4 & CT.5- Construction Methods & 14.17 & 93 \\
\hline 5 & $\begin{array}{l}\text { CT.4- Human Resource } \\
\text { Management }\end{array}$ & 14.08 & 92.4 \\
\hline 6 & $\begin{array}{c}\text { CT.2- Construction Machinery \& } \\
\text { Equipment Logistics }\end{array}$ & 14.05 & 92.2 \\
\hline \multicolumn{2}{|r|}{ SUM } & 100 & 656 \\
\hline
\end{tabular}

Fig 4.8 shows the category of execution approach has the highest ranking followed by material management. The category of Environment, Safety, and Health has ranked on third place. The category of Construction Methods and Human Resource Management scored fourth and fifth place in the category. The category of Construction Machinery \& Equipment Logistics has score the lowest rank. 


\section{International Journal of Science and Research (IJSR) \\ ISSN (Online): 2319-7064}

Index Copernicus Value (2013): 6.14 | Impact Factor (2015): 6.391

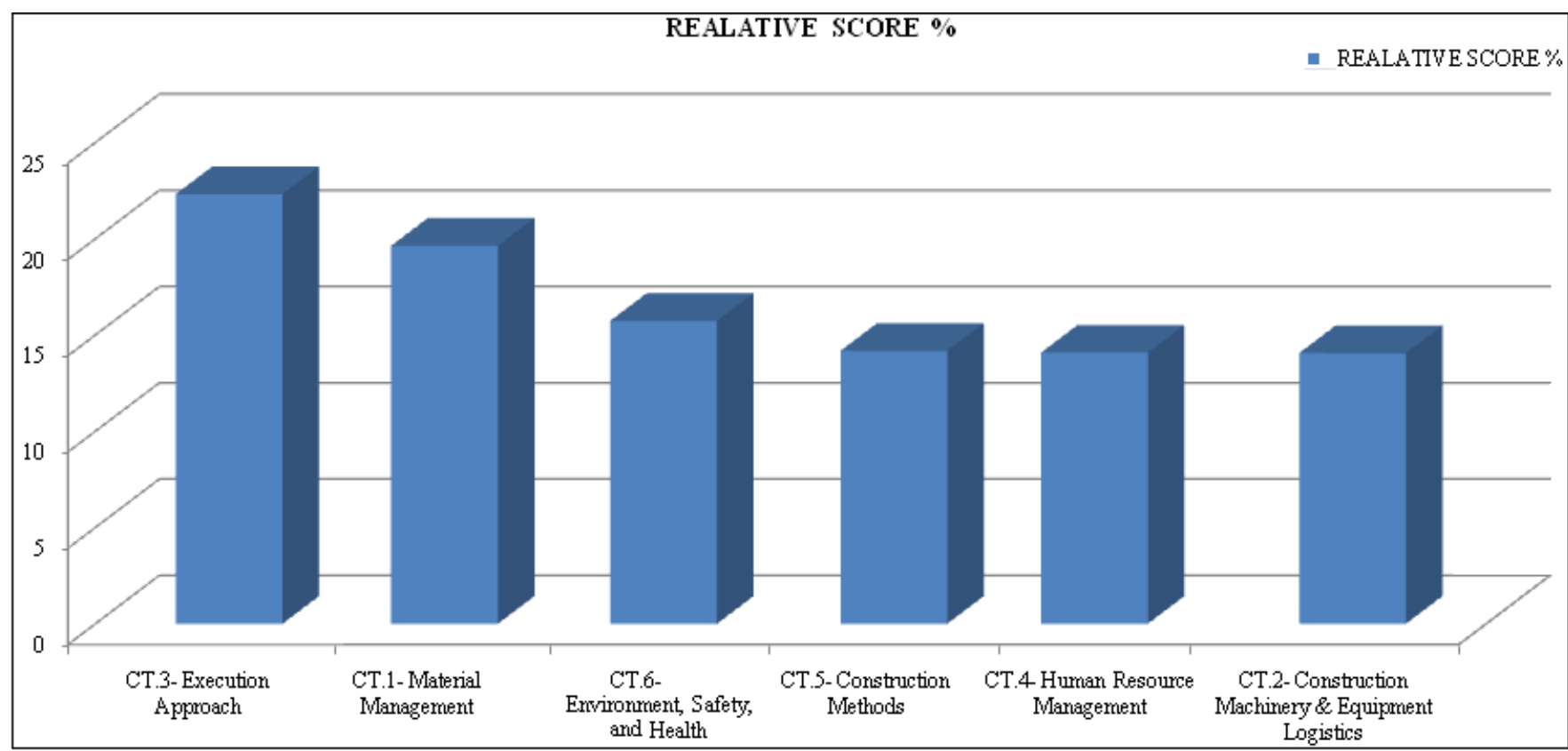

Figure 4.8: Ranking of Categories in BPPII Infrastructure

\subsection{Top Ranked Elements in the BPPII Infrastructure}

Table 4.10 provides the listing of top 10 ranking elements in the BPPII Infrastructure.

Table 4.10: Top Ranked Elements in the BPPII Infrastructure

\begin{tabular}{|c|c|c|}
\hline Ranking & Element & Score \\
\hline 1 & Contracts \& Agreements with Agencies & 27 \\
\hline 2 & Defining accurate materials specifications & 26 \\
\hline 2 & Use of Software & 26 \\
\hline 3 & $\begin{array}{c}\text { Drawings, site permits, and other required } \\
\text { documents were available before starting } \\
\text { construction. }\end{array}$ & 25 \\
\hline 3 & Dedicated planner & 25 \\
\hline 4 & $\begin{array}{c}\text { Construction Machinery and Equipment } \\
\text { Maintenance }\end{array}$ & 24.8 \\
\hline 5 & Well defined scope of work & 24 \\
\hline 5 & Model requirements/3d visualization & 24 \\
\hline 5 & $\begin{array}{l}\text { All necessary material, equipment, tools and } \\
\text { work permits were available before starting } \\
\text { construction. }\end{array}$ & 24 \\
\hline 5 & $\begin{array}{l}\text { Required construction and management } \\
\text { personnel were available as needed before } \\
\text { starting construction. }\end{array}$ & 24 \\
\hline 6 & Locating sources of materials for procurement & 23 \\
\hline 7 & On site Tools Maintenance & 22.8 \\
\hline 8 & $\begin{array}{l}\text { Site Tools and Equipment Management } \\
\text { Strategy }\end{array}$ & 22.6 \\
\hline 9 & Controlling over ordering and purchasing & 22 \\
\hline 9 & Procurement Procedures \& Plans for & 22 \\
\hline
\end{tabular}

\begin{tabular}{|l|c|c|} 
& Construction Machinery & \\
\hline 10 & Average working hours/day & 20.8 \\
\hline
\end{tabular}

Fig 4.9 shows the Ranked Elements in the BPPII Infrastructure It can be seen that some elements or practices have the same score. Contracts \& Agreements with Agencies have the highest ranking among the 31 elements of the index. Defining accurate materials specifications and Use of Software has been ranked on second position which shares the same ranking. Drawings, site permits, and other required documents were available before starting construction and Dedicated planner has been ranked on the third position which also shares the same ranking. Construction Machinery and Equipment Maintenance has been ranked on the fourth position. All necessary material, equipment, tools and work permits were available before starting construction; Model requirements/3d visualization and Well defined scope of work has been ranked on the fifth position respectively. Locating sources of materials for procurement has been ranked on sixth position. On site Tools Maintenance has ranked on seventh position followed by Site Tools and Equipment Management Strategy that is ranked on eight position. Controlling over ordering and purchasing and Procurement Procedures \& Plans for Construction Machinery both are simultaneously ranked on ninth position. Average working hours/day has been ranked on tenth position. There are 17 practices in the top 10 ranked and it makes almost $50 \%$ of the total index score. This shows the importance of these particular practices for the improvement of productivity on construction projects. 


\section{International Journal of Science and Research (IJSR) \\ ISSN (Online): 2319-7064}

Index Copernicus Value (2013): 6.14 | Impact Factor (2015): 6.391

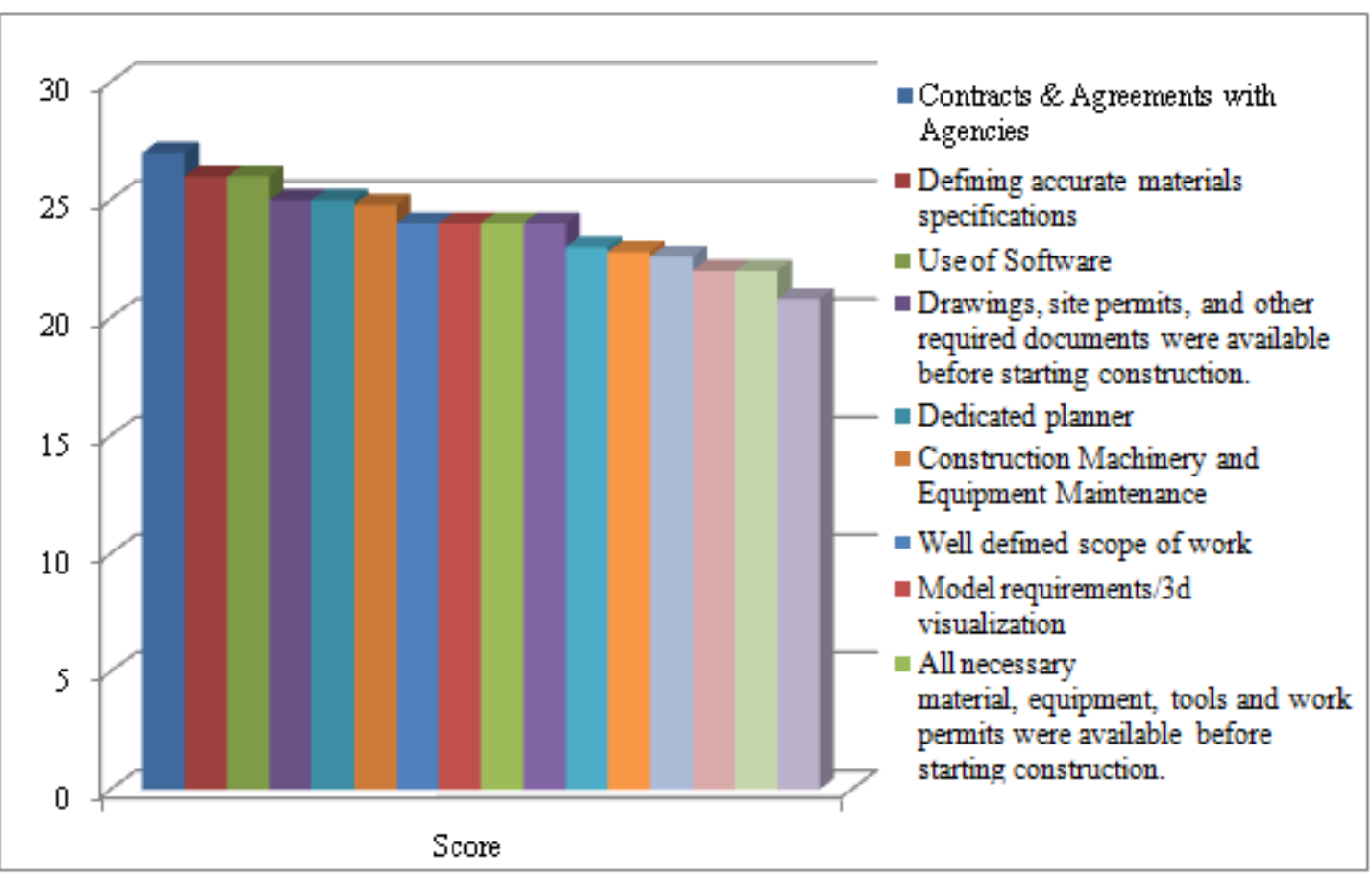

Figure 4.9: Top 10 Ranked Elements in the BPPII Infrastructure

\section{Conclusions}

This chapter presents conclusion of dissertation that can be carried out on basis of the present work. The conclusion summarizes the overall work that has been carried out in this dissertation. The future scope provides the direction for extension of the presented work.

\subsection{Conclusion}

Various different factors affect project performance whereas labour productivity is recognized as one of the most important factor in construction industry. So the objective behind this research was to address this critical aspect of project performance. The goal was to improve the effective planning and implementing of management practices that positively impact construction productivity. The main role of this paper is the development of a method called BPPII Industrial.

The BPPII Industrial includes 31 elements, also called best productivity practices, which were grouped in six categories: (1) Materials Management, (2) Construction Machinery \& Equipment Logistics, (3) Equipment Logistics, (4) Human Resources Management, (5) Construction Methods, and (6) Environment, Health, and Safety. In developing the BPPII Industrial, relevant literature took into account. The PIL method is used to find maximum score of each category and each element. Further the category are ranked on the basis of the score obtained by the PIL. The category Execution Approach score the highest in all the category with the score of 146.

Further the top 10 element are ranked according to their score. The very first element is Contracts \& Agreements with Agencies. As this practice should given a very high importance before starting of any construction project.

\subsection{Future Scope}

This study is conducted for Government and private organization in Amravati and nearby districts where questionnaire survey was carried out from few respondents. To understand more about the exact scenario, scope and number of respondents can be increased. Similar tool based on PIL of best practices should also developed for various construction industry.

\section{References}

[1] (Carlos H. Caldas et al. 2014) "Method to Assess the Level of Implementation of Productivity Practices on Construction Projects" Journal of construction Engineering and Management, ASCE ISSN 0733-9364.

[2] (Hassan Nasir 2013) "Best Productivity Practices Implementation Index (BPPII) for Infrastructure Projects" Waterloo, Ontario, Canada, 2013.

[3] (Hassan Nasir et al. 2015) "An Integrated Productivity Practices Implementation Index for Planning the Execution Of Infrastructure Project" Journal of Infrastructure systems ASCE, ISSN 1076-0342.

[4] (Rojas and Aramvareekul 2003) "Labour productivity drivers and opportunities in the construction industry." J. Manage. Eng., 10.1061/ (ASCE)0742597X(2003)19:2(78), 78-82.

[5] Allmon et al. 2000) "U.S. construction labour productivity trends, 1970-1998." J. Constr. Eng. Manage., 10.1061/(ASCE)0733-9364(2000)126:2(97), 97-104.

[6] (Shan et al. 2011) "The impact of management practices on mechanical construction productivity." Constr. Manage. Econ., 29(3), 305-316.

[7] (Liberda et al. 2003) "Construction productivity improvement: A study of human, management and external issues." Construction Research Congress, ASCE, Reston, VA, 1-8. 


\section{International Journal of Science and Research (IJSR) \\ ISSN (Online): 2319-7064}

Index Copernicus Value (2013): 6.14 | Impact Factor (2015): 6.391

[8] (Dai et al. 2009) "Construction craft workers' perceptions of the factors affecting their productivity." J. Constr. Eng. Manage., 10.1061/(ASCE)07339364(2009)135:3(217), 217-226.

[9] (Borcherding and Garner 1981) "Work force motivation and productivity on large jobs." J. Constr. Div., 107(3), 443-453.

[10](Eddy M. Rojas 2003) "Is construction labour productivity really declining?" J. Constr. Eng. Manage., 10.1061/(ASCE)0733- 9364(2003)129:1(41), 41-46

[11] (Paul M. Goodrum et al.) "Long-term impact of equipment technology on labor productivity in the U.S. Construction Industry at the activity level." J. Constr. Eng. $\quad$ Manage., 10.1061/(ASCE)0733-9364 (2004)130:1(124), 124-133.

\section{Annexure 1}

\section{Questionnaire}

Please indicate by ticking the appropriate column the relative importance of each of the following .You have to tick mark ( ) in any one column for each row of element according to experience for identifying elements which affecting construction labor productivity.

1= Not important, 2= low important, 3= Moderately important, 4=Important, 5= Very important.

\begin{tabular}{|c|c|c|c|c|c|c|c|c|}
\hline \multirow{2}{*}{$\begin{array}{l}\text { Sr. } \\
\text { No }\end{array}$} & \multirow{2}{*}{ Group } & \multirow{2}{*}{ Element } & \multicolumn{5}{|c|}{ Relative Importance } & \multirow{2}{*}{ Total } \\
\hline & & & 1 & 2 & 3 & 4 & 5 & \\
\hline 1 & \multirow{6}{*}{$\begin{array}{l}\text { Materials } \\
\text { Management }\end{array}$} & Defining accurate materials specifications & & & & & & \\
\hline 2 & & Locating sources of materials for procurement & & & & & & \\
\hline 3 & & Preparing for material storage & & & & & & \\
\hline 4 & & Daily recording of using materials in the project & & & & & & \\
\hline 6 & & Controlling over ordering and purchasing & & & & & & \\
\hline 8 & & Co-workers are mishandling the materials due to lack of training & & & & & & \\
\hline 10 & \multirow{4}{*}{$\begin{array}{l}\text { Construction } \\
\text { Machinery \& } \\
\text { Equipment } \\
\text { Logistics }\end{array}$} & Procurement Procedures \& Plans for Construction Machinery & & & & & & \\
\hline 11 & & Construction Machinery and Equipment Maintenance & & & & & & \\
\hline 16 & & Site Tools and Equipment Management Strategy & & & & & & \\
\hline 18 & & On site Tools Maintenance & & & & & & \\
\hline 20 & \multirow{7}{*}{$\begin{array}{l}\text { Execution } \\
\text { Approach }\end{array}$} & Short interval planning & & & & & & \\
\hline 21 & & Well defined scope of work & & & & & & \\
\hline 22 & & Use of Software & & & & & & \\
\hline 23 & & Dedicated planner & & & & & & \\
\hline 26 & & Contract types/strategies & & & & & & \\
\hline 27 & & Model requirements/3d visualization & & & & & & \\
\hline 29 & & Contracts \& Agreements with Agencies & & & & & & \\
\hline 30 & \multirow{5}{*}{$\begin{array}{l}\text { Human Resource } \\
\text { Management }\end{array}$} & Age factor & & & & & & \\
\hline 31 & & Average working hours/day & & & & & & \\
\hline 33 & & Site crowding factor enables labours to do work in uncomfortable manner. & & & & & & \\
\hline 34 & & Over time work will not give good productivity in an job & & & & & & \\
\hline 36 & & On time payment is done right at the time when the work is accomplished. & & & & & & \\
\hline 38 & \multirow{4}{*}{$\begin{array}{l}\text { Construction } \\
\text { Methods }\end{array}$} & $\begin{array}{c}\text { The construction team (including the owner, engineering and Procurement) was } \\
\text { both integrated and aligned. }\end{array}$ & & & & & & \\
\hline 39 & & $\begin{array}{c}\text { Drawings, site permits, and other required documents were available before } \\
\text { starting construction. }\end{array}$ & & & & & & \\
\hline 40 & & $\begin{array}{c}\text { All necessary material, equipment, tools and work permits were available } \\
\text { before starting construction. }\end{array}$ & & & & & & \\
\hline 42 & & $\begin{array}{l}\text { Required construction and management personnel were available as needed } \\
\text { before starting construction. }\end{array}$ & & & & & & \\
\hline 45 & \multirow{6}{*}{$\begin{array}{l}\text { Environment, } \\
\text { Safety, and } \\
\text { Health }\end{array}$} & Formal Health and Safety Policy & & & & & & \\
\hline 46 & & Climatic condition will affect your working performance & & & & & & \\
\hline 47 & & Site safety procedures were followed for the project. & & & & & & \\
\hline 51 & & Safety incentives were used on the project. & & & & & & \\
\hline 53 & & Accidents were formally investigated. & & & & & & \\
\hline 54 & & Contractor employees were randomly screened for alcohol and drugs. & & & & & & \\
\hline
\end{tabular}

Date: Engineer Name

Designation
[12](William F. Maloney) "PRODUCTIVITY IMPROVEMENT: THE INFLUENCE OF LABOR" Journal of Construction Engineering and Management, Vol. 109, No. 3, September, 1983. CASCE, ISSN 07339364/83/0003-0321/\$01.00. Paper No. 18214.

[13] (Upul Ranasinghe1 et.al.) "Streamlining the Construction Productivity Improvement Process with the Proposed Role of a Construction Productivity Improvement" Journal of Construction Engineering and Management, Vol. 138, No. 6, June 1, 2012. CASCE, ISSN 0733-9364/2012/6-697-706.

[14] (Jimmie Hinze and Gary Wilson 2000) "Moving toward a zero injury objective." J. Constr. Eng. Manage., 10.1061/(ASCE)0733-9364(2000)126:5(399), 399-403. 